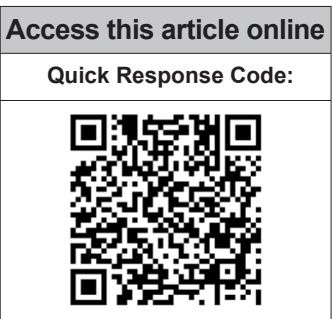

Website:

www.jponline.org

DOI:

10.4103/JLP.JLP_58_18
Departments of Pathology and ${ }^{1}$ Surgery, University College of Medical Sciences, New Delhi, India

Address for correspondence: Dr. Nadeem Tanveer, Department of Pathology, University College of Medical Sciences,

Dilshad Garden,

New Delhi - 110095 , India. E-mail: ntobh104@yahoo.

Submission: 23-04-2018 Accepted: 11-09-2018

\title{
Y-Box binding protein 1 expression in breast cancer and its correlation with hormone receptors and other prognostic markers
}

\author{
Taruna Bansal, Nadeem Tanveer, Usha Rani Singh, Sonal Sharma, Navneet Kaur ${ }^{1}$
}

\begin{abstract}
:
INTRODUCTION: The present histologic and immunohistochemical prognostic markers of breast carcinoma do not effectively identify the subset of patients with poor prognosis. Y-Box binding protein 1 (YB1) is a novel biomarker which may identify and aid in targeted personalized therapy for such patients.

MATERIALS AND METHODS: The study was conducted on histopathology specimens of 74 patients of breast carcinoma who had undergone modified radical mastectomy. YB1 immunohistochemistry (IHC) was performed on manual tissue microarray blocks (each having 15 cores). The YB1 expression was quantified in terms of "immunoreactive score" which was correlated with clinical parameters, hormone receptor status, and Her2neu overexpression by IHC. The Her2neu status of the equivocal cases was further evaluated by fluorescent in situ hybridization (FISH).
\end{abstract}

RESULTS: YB1 was positive in 36/74 (48.6\%) cases. On IHC and analysis by FISH, 25/74 (34\%) cases had Her2neu overexpression. Estrogen receptor (ER) and progesterone receptor (PR) positivity was found in $42 \%$ and $36.5 \%$ cases, respectively. YB1 immunopositivity was negatively correlated with ER and PR expression, but showed a significant positive correlation with Her2neu expression. No correlation was found with other clinical parameters, tumor stage, and grade, except lymph node involvement, which showed a positive association with YB1 expression. Triple-negative breast carcinoma constituted $25.6 \%$ of the total cases, out of which $73.6 \%$ were YB1 positive.

CONCLUSION: This study found that YB1 has an association with Her2neu expression. It may in future provide a therapeutic target in Her2neu overexpressing tumors.

Key words:

Manual tissue microarray, triple-negative breast carcinoma, Y-Box binding protein 1

\section{Introduction}

$\neg$ hough clinically and morphologically 1 cases of carcinoma breast may appear similar, genetically they form a divergent group. Hence, novel genetic markers are needed to prognosticate and stratify cases of breast cancer for appropriate therapy.

Y-Box binding protein 1 (YB1) is a nucleic acid-binding protein encoded by gene YBX1,

This is an open access journal, and articles are distributed under the terms of the Creative Commons Attribution-NonCommercial-ShareAlike 4.0 License, which allows others to remix, tweak, and build upon the work non-commercially, as long as appropriate credit is given and the new creations are licensed under the identical terms.

For reprints contact: reprints@medknow.com which was initially identified as a factor bound to the Y-box (an inverted CCAAT box). ${ }^{[1,2]} \mathrm{It}$ is a pleiotropic, multifunctional protein with many functions including regulation of transcription, translation, cell survival, DNA replication and repair, drug resistance, and epithelial-mesenchymal transition..$^{[2]}$ It contains a highly conserved cold shock domain, which is involved in binding nucleic acid including RNA as well as dsDNA. ${ }^{[3]}$

Within the nucleus, YB1 binds to inverted CCAAT boxes known as YB-1-responsive

How to cite this article: Bansal $\mathrm{T}$, Tanveer $\mathrm{N}$, Singh UR, Sharma S, Kaur N. Y-Box binding protein 1 expression in breast cancer and its correlation with hormone receptors and other prognostic markers. J Lab Physicians 2018;10:420-5. 
elements to activate or repress transcription. ${ }^{[2]}$ YB1 has been shown to interact with the epidermal growth factor receptor (EGFR) enhancer and the Her 2 promoter and also induces transcription of drug-resistant genes including the multidrug resistance-1 (MDR1) and multi-drug resistance-related protein- $1 .{ }^{[4-6]}$

In the cytoplasm, YB1 is found in complexes with translationally inactive mRNAs. ${ }^{[7]}$ This has led to the notion that YB1 is involved in translational repression.

YB1 is expressed in various malignancies including breast carcinoma, colorectal carcinomas, ovarian serous adenocarcinoma, prostate adenocarcinoma, lung carcinoma, large B-cell lymphoma, multiple myeloma, osteosarcoma, embryonal rhabdomyosarcoma, glioblastoma multiforme, and melanoma. ${ }^{[8]}$ Little is known about the mechanism involved in the overexpression of YB1 in cancers. It was once postulated that it occurred due to gene amplification. However, gene mapping and comparative genomic hybridization failed to reveal any amplification at chromosome $1 \mathrm{p} 34 .{ }^{[9]}$ Thus, the high expression of YB1 in breast cancer does not appear to be due to gain in copy number and could be due to transcriptional activation. ${ }^{[10]}$

In all the studies done so far, YB1 expression correlated with a poor patient prognosis. Tumors expressing high YB-1 had significantly decreased disease-free and recurrence-free survival.

Studies have shown YB1 protein to be elevated in a range of $36 \%-41 \%$ of breast cancers. ${ }^{[11,12]}$ As in other malignancies, increased expression of YB1 in breast cancer is associated with a poorer prognosis in terms of decreased patient survival and increased recurrence rates. ${ }^{[13]}$ Nuclear localization of YB1 is thought to be associated with intrinsic MDR1 gene expression. ${ }^{[5]}$ Studies have further concluded that overexpression of YB1 may be an initiating event for early development of breast cancer by causing centrosome amplification, chromosomal instability, and aneuploidy, hence a potential target for therapy. ${ }^{[8]}$

The Her2 proto-oncogene is located on chromosome $17 q 21$. Her 2 is found to be amplified in $20 \%-30 \%$ of breast cancer. ${ }^{[14]}$ Her 2 positivity is associated with a number of adverse tumor characteristics such as larger tumor size, higher nuclear grade, and S-phase fraction. ${ }^{[15]}$ YB1 directly induces transcription of EGFR and Her2 in a S102-dependent manner. ${ }^{[16]}$

\section{Materials and Methods}

This study was performed on 74 histologically confirmed cases of breast carcinoma from October 2015 to April 2017.
All these patients had undergone modified radical mastectomy. The study was cleared by the Institutional Ethics Committee and informed patient consent was taken. Clinical data of the patients were recorded from the histopathology requisition forms. All the specimens were fixed in 10\% buffered formalin and embedded in paraffin wax. Sections stained with hematoxylin and eosin were used to identify the histological type of breast cancer and study other histological features such as presence of in situ component, lymph node status, and grading of the tumor. For grading, Nottingham modification of the Bloom Richardson system and for staging, American Joint Committee on Cancer staging were used. ${ }^{[17,18]}$

Manual tissue microarray (TMA) without prefabricated recipient block using bone marrow biopsy needle was made as described by Chen and Zhou as it was found to be superior to the technique described by Kononen et al. in our department. ${ }^{[19,20]}$ We constructed six TMA blocks for 74 cases. Each TMA block comprised of tissues from 12 to 15 cases.

\section{Immunohistochemistry procedure}

3-4 $\mu \mathrm{m}$-thick sections were taken from each microarray block for hematoxylin and eosin staining and ER, PR, Her-2, and YB1 detection by immunohistochemistry (IHC) on poly-1-lysine-coated slides. The rabbit polyclonal anti-YB1 protein antibody (orb 336555 biorbyt, UK) was used in a dilution of 1:200. Sections from human duodenal biopsy were taken as positive control for YB1 protein expression [Figure 1a].

\section{Immunohistochemical analysis}

The IHC staining was assessed as percentage of positive staining cells. For interpretation of ER, PR protein expression nuclear staining was assessed [Figure $2 a$ and $b$ ]. $>10 \%$ of cells showing positive nuclear staining for ER/ PR were considered positive. For Her-2, 0-1+ was taken as negative and $3+$ as positive (ASCO/CAP guidelines 2013) [Figure 2c, d and Table 1]. ${ }^{[21]}$ Cases which were equivocal $(2+)$ by IHC were further evaluated for Her2 amplification by fluorescent in situ hybridization (FISH). For YB1, nuclear staining was assessed by "Immune-reactive score" [Table 2]. The result is the product of the two scores, ranging from 0 to 12 , considering YB1 $<6$ as negative expression and $\mathrm{YB} 1 \geq 6$ as positive expression [Figure 1]. ${ }^{[22]}$

\section{Fluorescent in situ hybridization}

ZytoLight SPEC ERBB2/CEN17 Dual Color Probe Kit was used for the detection of Her2 gene amplification by FISH. The probe contained green-labeled polynucleotides (ZyGreen: Excitation at $503 \mathrm{~nm}$ and emission at $528 \mathrm{~nm}$ ), which targets the ERBB2 gene and orange-labeled polynucleotides (ZyOrange: Excitation 


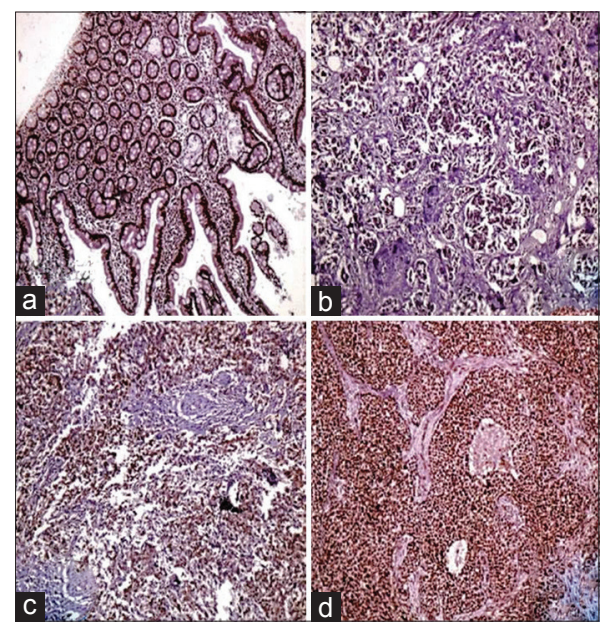

Figure 1: (a) Human duodenal biopsy (control) showing nuclear and cytoplasmic expression of Y-Box binding protein 1antibody, $\times 100$; (b) negative nuclear Y-Box binding protein 1 expression; score 3, $\times 100$; (c) moderate positivity of nuclear Y-Box binding protein 1 expression; score $9, \times 100$; (d) strong positivity of nuclear Y-Box binding protein 1 expression; score $12, \times 100$

Table 1: Estrogen receptor, progesterone receptor, and Her2 scoring

\begin{tabular}{|c|c|c|c|}
\hline & ER & PR & Her2 \\
\hline Negative & 0 & 0 & $\begin{array}{l}\text { No staining or membrane } \\
\text { staining which is incomplete } \\
\text { and is faint/barely perceptible } \\
\text { and within } \leq 10 \% \text { of tumor } \\
\text { cells }\end{array}$ \\
\hline $1+$ & $\begin{array}{l}<10 \% \text { cells show } \\
\text { positive staining }\end{array}$ & $<10 \%$ & $\begin{array}{l}\text { Incomplete membrane } \\
\text { staining that is faint/barely } \\
\text { perceptible and within }>10 \% \\
\text { of tumor cells }\end{array}$ \\
\hline $2+$ & $10 \%-75 \%$ & $10 \%-75 \%$ & $\begin{array}{l}\text { Circumferential membrane } \\
\text { staining that is incomplete } \\
\text { and/or weak/moderate and } \\
\text { within }>10 \% \text { of tumor cells OR } \\
\text { complete and circumferential } \\
\text { membrane staining that is } \\
\text { intense and within } \leq 10 \% \text { of } \\
\text { tumor cells }\end{array}$ \\
\hline $3+$ & $>75 \%$ & $>75 \%$ & $\begin{array}{l}\text { Circumferential membrane } \\
\text { staining that is complete, } \\
\text { intense, and within }>10 \% \text { of } \\
\text { tumor cells }\end{array}$ \\
\hline
\end{tabular}

$\mathrm{ER}=$ Estrogen receptor, $\mathrm{PR}=$ Progesterone receptor

Table 2: Y-Box binding protein 1 immuno-reactive scoring

\begin{tabular}{ll}
\hline Percentage of positive cells & Intensity of reaction \\
\hline$\leq 25 \%$ positive cells -1 & Negative staining - 0 \\
$26 \%-50 \%$ positive cells -2 & Weak staining -1 \\
$51 \%-75 \%$ positive cells -3 & Moderate staining -2 \\
$\geq 75 \%$ positive cells -4 & Strong staining - 3 \\
\hline
\end{tabular}

at $547 \mathrm{~nm}$ and emission at $572 \mathrm{~nm}$ ), which targets alpha-satellite sequences of the centromere of chromosome 17. Duplex formation of the fluorescence-labeled probes was visualized using Nikon Eclipse 80i flourescence microscope (Nikon Corporation) employing red and

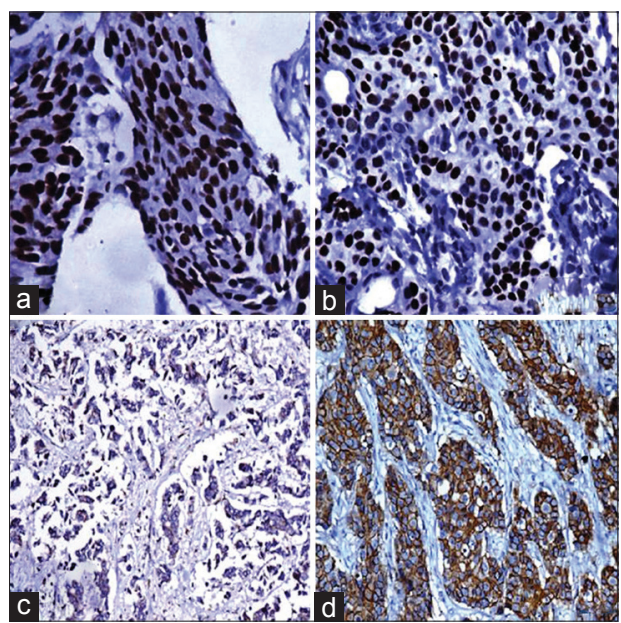

Figure 2: (a) Positive estrogen receptor expression (3+), $\times 400$; (b) positive progesterone receptor expression (3+), $\times 400$; (c) negative Her2 expression, $\times 100$; (d) positive Her2 expression (3+), $\times 200$

green filters. In interphases of normal cells or cells without aberrations of chromosome 17, two ERBB2 signals and two chromosome 17 signals appeared and were taken as normal.

\section{Results}

\section{Y-Box binding protein 1 immunoexpression}

YB1 expression was studied by IHC. The expression levels were then correlated with clinicomorphological parameters including age, side, menopausal status, grade, stage, lymph node status, presence/absence of in situ component, and hormone receptor status [Table 3].

In our study, YB1 showed cytoplasmic positivity in all the cases, whereas nuclear expression of YB1 was found to be positive in $48.6 \%$ cases and had a significant association with Her2 positivity and ER and PR negativity [Table 4]. For the purpose of our study, only nuclear expression was taken as positive. However, no association was found with tumor grade and stage. Lymph node metastasis had significant positive correlation with YB1 expression [Table 3].

Her2 gene amplification analysis by fluorescent in situ hybridization

Analysis of Her2 amplification by FISH was done on TMA slides. Her2 gene amplification was found in all three IHC equivocal (score $2+$ ) cases. The cells having Her2/CEP17 ratio $\geq 2$ or Her2/CEP17 ratio $<2$ with average Her2 copy number $\geq 6$ signals/cell were taken as positive (as per ASCO/CAP guidelines) [Figure $3 a$ and $b$ ].

\section{Discussion}

YB1 protein is a multifunctional protein having a role in transcription, translation, and DNA repair. 
Table 3: Distribution of the clinicopathological parameters included in the study

\begin{tabular}{|c|c|c|c|}
\hline \multirow{2}{*}{$\begin{array}{l}\text { Clinicopathological } \\
\text { parameter }\end{array}$} & \multicolumn{2}{|c|}{ Percentage of cases } & \multirow{2}{*}{$\begin{array}{l}\text { Association } \\
\text { with YB1 } \\
\text { expression }(P)\end{array}$} \\
\hline & Present & Absent & \\
\hline \multicolumn{4}{|l|}{ Histological type } \\
\hline IDC-NOS & 70/74 (95) & & 0.164 \\
\hline $\begin{array}{l}\text { Invasive mucinous } \\
\text { carcinoma }\end{array}$ & 3 & & \\
\hline $\begin{array}{l}\text { IDC with medullary } \\
\text { features }\end{array}$ & 1 & & \\
\hline $\begin{array}{l}\text { Invasive lobular } \\
\text { carcinoma }\end{array}$ & 1 & & \\
\hline In situ component & $54 / 74(72.3)$ & $20 / 74(27.7)$ & 1 \\
\hline \multicolumn{4}{|l|}{ Tumor grade ${ }^{* \star}$} \\
\hline Grade 1 & $13 / 65(20)$ & & 0.333 \\
\hline Grade 2 & $44 / 65(67.7)$ & & \\
\hline Grade 3 & 8/65 (12.3) & & \\
\hline \multicolumn{4}{|l|}{$\begin{array}{l}\text { Pathological }(\mathrm{T}) \\
\text { staging }\end{array}$} \\
\hline $\mathrm{T} 1$ & 3 & & 0.28 \\
\hline $\mathrm{T} 2$ & 69 & & \\
\hline T3 & 19 & & \\
\hline $\mathrm{T} 4$ & 9 & & \\
\hline $\begin{array}{l}\text { Lymph node } \\
\text { metastasis" }\end{array}$ & $42 / 72(58.33)$ & $30 / 72(41.67)$ & 0.02 \\
\hline \multicolumn{4}{|l|}{ Molecular subtypes } \\
\hline Luminal A & 40 & & \\
\hline Luminal B & 19 & & \\
\hline Her2 positive & 15 & & \\
\hline Triple negative & 26 & & \\
\hline
\end{tabular}

${ }^{* *} 9 / 74$ cases were postchemotherapy, hence not graded, "Data regarding lymph node status of two cases were not available. IDC-NOS = Invasive ductal carcinoma-not otherwise specified, YB1 = Y-Box binding protein 1

Table 4: Distribution of Y-Box binding protein 1 according to Her2, estrogen receptor, and progesterone receptor expression among study cases

\begin{tabular}{lccc}
\hline & $\begin{array}{c}\text { YB1 positive } \\
(n=36), n(\%)\end{array}$ & $\begin{array}{c}\text { YB1 negative } \\
(n=38), n(\%)\end{array}$ & $P$ \\
\hline Her2 positive $(n=25)$ & $19(76)$ & 6 & 0.0012 \\
Her2 negative $(n=49)$ & 17 & $32(65.3)$ & \\
ER positive $(n=31)$ & $8(25.8)$ & $23(74.2)$ & 0.001 \\
ER negative $(n=43)$ & $28(65)$ & $15(35)$ & \\
PR positive $(n=27)$ & $5(18.5)$ & $22(81.5)$ & 0.0001 \\
PR negative $(n=47)$ & $31(66)$ & $16(34)$ & \\
\hline
\end{tabular}

$\mathrm{ER}=$ Estrogen receptor, $\mathrm{PR}=$ Progesterone receptor, $\mathrm{YB} 1=\mathrm{Y}$-Box binding protein 1

An increased YB1 expression was demonstrated in not only breast cancer but also various other tumors that include osteosarcoma, prostate cancer, glioblastoma, and ovarian malignancies. ${ }^{[22]}$ It induces cell proliferation, apoptosis, and control of tumor response to chemotherapy. ${ }^{[22]}$

Previous studies on YB1 expression in breast cancer have supported its utility as an independent prognostic and predictive marker in breast cancer management.
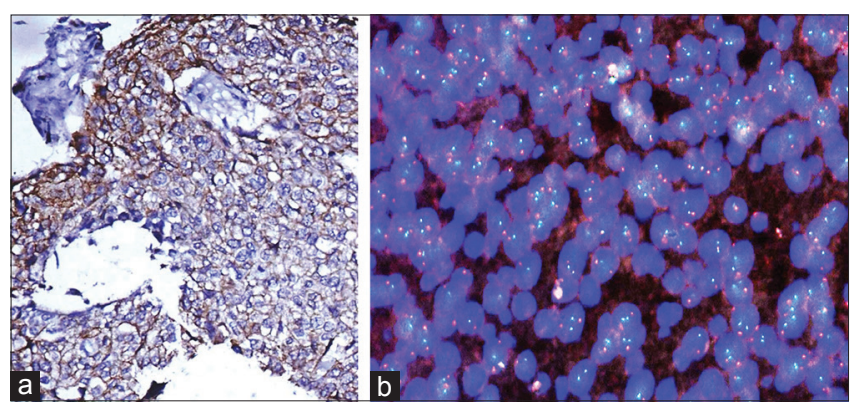

Figure 3: (a) A case equivocal on immunohistochemistry for Her2 (2+); (b) photomicrograph showing Her2 gene amplification by fluorescent in situ hybridization, with the cells having Her2/CEP17 ratio $\geq 2$

Her2 in breast cancer is overexpressed either due to gene amplification or via transcriptional activation through increased tyrosine kinase activity and phosphorylation of itself and cellular substrates. Her2 and Her3 coexpression activates the downstream PI3k/Akt pathway which is considered to be a tumorigenic function of overexpressed Her2. ${ }^{[23]}$ In our study, Her-2 was positive in $33.7 \%$ of cases. Studies have reported a wider range of positivity from $10 \%$ to $34 \% .{ }^{[24]}$ In our study, nuclear expression of YB1 was found to be positive in $48.6 \%$ of cases and had a significant association with Her2 positivity. However, no association was found with tumor grade, stage, histological subtype, presence of in situ component, or other clinical parameters such as age or menopausal status.

Studies have reported YB1 overexpression in 36\%-41\% of human breast cancers, while $80 \%$ of primary breast tumors showed increased copy numbers of chromosome 1. ${ }^{[5,12]}$ Wang et al. conducted their study on 1094 breast cancer patients and found YB1 overexpression in 398/1094 $(36.38 \%)$ of cases. ${ }^{[13]}$ Bergmann et al. constructed TMA representing 4049 cases of invasive breast cancer with 20 years of follow-up and found YB1 expression in $41 \%$ of cases ${ }^{[8]}$ In a similar study in 239 breast cancer cases, nuclear YB1 expression was found to be positive in $36.8 \%$ of cases. ${ }^{[25]}$

A significant association was found between YB1 expression and Her2 receptor overexpression in our study $(P=0.0012)$. Wang et al. also found a significant association between YB1 expression and Her2 positivity. ${ }^{[13]}$

Few other studies have suggested that YB1 acts as a promoter of Her2, and its expression leads to the clonal selection and expansion of Her2-positive cells. ${ }^{[25,26]}$ Similar results were obtained in another study, which reported that YB1 directly binds to the Her2 promoter in cells where Her2 gene was amplified. It thus allowed the cells with Her2 amplification to slip through the cell cycle check points and promote tumor growth. ${ }^{[6]}$ Her2 
expression can thus be downregulated by silencing YB1 using SiRNA to knock down its expression or by mutating YB1 $\left(\right.$ Ser $\left.^{102}\right) \cdot{ }^{[6]}$ Patients with Her2 receptor positivity and hormone receptor negativity have been found to have an unfavorable prognosis and higher risk of recurrence. YB1 expression acting via Her2-Akt-dependent pathway might be responsible for this poor prognosis. ${ }^{[27]}$ Hence, it has been suggested that the YB1-Her2 axis can be very important for personalized therapeutics in breast cancer by YB1-targeted drugs. Bergmann et al. reported that $\mathrm{YB} 1$ was expressed in $65 \%$ of Her2-positive breast cancer. In our study, we found YB1 to be positive in $76 \%$ of Her2-positive cases. ${ }^{[8]}$

Lymph node status and tumor stage are important prognostic factors in breast cancer management. In our study, we found significant association between YB1 expression and lymph node status, suggesting the role of YB1 in prognostication. ${ }^{[22]}$

In another study, YB1 was expressed in 30\% of node-negative cases and based on the results, the authors suggested that patients with node-positive or node-negative cancer were more likely to die from the disease if YB1 was expressed. ${ }^{[8]}$ Xie et al. also found a significant positive correlation of YB1 with tumor grade and Her2 expression and a negative correlation with ER expression. ${ }^{[25]}$

Our study showed both cytoplasmic and nuclear expression of YB1. For the purpose of analysis, only the nuclear expression of YB1 was considered positive. Studies in the past have also demonstrated both cytoplasmic and nuclear YB1 expression. ${ }^{[28]}$ Other workers have also found cytoplasmic YB1 expression in $100 \%$ of their cases. ${ }^{[25]}$ However, nuclear expression of YB1 was found only in $48.6 \%$ of our study cases. Different YB1 antibodies show different staining patterns that are determined by the accessibility of epitopes, and this depends on the nature of YB1 complexes. Hence, it is important to standardize the protocols and validate the staining with transcription of the protein if YB1 is to be used reproducibly as a prognostic guide for different cancers. ${ }^{[11]}$

Studies have found YB1 expression in $70 \%-75 \%$ of triple-negative breast cancer (TNBC) and have found YB1 to be crucial in the genesis and maintenance of TNBC. ${ }^{[25]}$ In our study, TNBC constituted $25.6 \%$ of all cases and YB1 expression was seen in $73.6 \%$ of these cases. Targeting YB1 in TNBC may be a useful therapeutic option. Post chemoresponse or survival data were not available for the cases, and further studies with larger sample size and adequate follow-up data would strengthen the role of YB1 in the prognostication of Indian breast cancer patients.

\section{Limitations of the study}

This study could only study YB1 in relation to breast carcinoma though it has been associated with many other carcinomas. The other limitation was that follow-up of the patients was not available to validate the prognostic role of YB1 in breast carcinoma patients.

\section{Conclusion}

This study found that YB1 has an association with Her2neu expression in breast carcinoma. It may in future provide a therapeutic target in Her2neu overexpressing tumors.

\section{Financial support and sponsorship}

This study was financially supported by Intramural Research Grant from the college.

\section{Conflicts of interest}

There are no conflicts of interest.

\section{References}

1. Liu X, Pogo BG. Inhibition of erbB-2-positive breast cancer cell growth by erbB-2 antisense oligonucleotides. Antisense Nucleic Acid Drug Dev 1996;6:9-16.

2. Lasham A, Samuel W, Cao H, Patel R, Mehta R, Stern JL, et al. YB-1, the E2F pathway, and regulation of tumor cell growth. J Natl Cancer Inst 2012;104:133-46.

3. Bouvet P, Matsumoto K, Wolffe AP. Sequence-specific RNA recognition by the xenopus Y-box proteins. An essential role for the cold shock domain. J Biol Chem 1995;270:28297-303.

4. Sakura H, Maekawa T, Imamoto F, Yasuda K, Ishii S. Two human genes isolated by a novel method encode DNA-binding proteins containing a common region of homology. Gene 1988;73:499-507.

5. Bargou RC, Jürchott K, Wagener C, Bergmann S, Metzner S, Bommert $\mathrm{K}$, et al. Nuclear localization and increased levels of transcription factor YB-1 in primary human breast cancers are associated with intrinsic MDR1 gene expression. Nat Med 1997;3:447-50.

6. Stein U, Jürchott K, Walther W, Bergmann S, Schlag PM, Royer HD, et al. Hyperthermia-induced nuclear translocation of transcription factor YB-1 leads to enhanced expression of multidrug resistance-related $\mathrm{ABC}$ transporters. J Biol Chem 2001;276:28562-9.

7. Evdokimova VM, Ovchinnikov LP. Translational regulation by Y-box transcription factor: Involvement of the major mRNA-associated protein, p50. Int J Biochem Cell Biol 1999;31:139-49.

8. Bergmann S, Royer-Pokora B, Fietze E, Jürchott K, Hildebrandt B, Trost D, et al. YB-1 provokes breast cancer through the induction of chromosomal instability that emerges from mitotic failure and centrosome amplification. Cancer Res 2005;65:4078-87.

9. Habibi G, Leung S, Law JH, Gelmon K, Masoudi H, Turbin D, et al. Redefining prognostic factors for breast cancer: $\mathrm{YB}-1$ is a stronger predictor of relapse and disease-specific survival than estrogen receptor or HER-2 across all tumor subtypes. Breast Cancer Res 2008;10:R86.

10. Wu J, Stratford AL, Astanehe A, Dunn SE. YB-1 is a transcription/Translation factor that orchestrates the oncogenome by hardwiring signal transduction to gene expression. Transl Oncogenomics 2007;2:49-65. 
11. Woolley AG, Algie M, Samuel W, Harfoot R, Wiles A, Hung NA, et al. Prognostic association of YB-1 expression in breast cancers: A matter of antibody. PLoS One 2011;6:e20603.

12. Fehm T, Morrison L, Saboorian H, Hynan L, Tucker T, Uhr J, et al. Patterns of aneusomy for three chromosomes in individual cells from breast cancer tumors. Breast Cancer Res Treat 2002;75:227-39.

13. Wang X, Guo XB, Shen XC, Zhou H, Wan DW, Xue XF, et al. Prognostic role of $\mathrm{YB}-1$ expression in breast cancer: A meta-analysis. Int J Clin Exp Med 2015;8:1780-91.

14. Lantz E, Cunningham I, Higa GM. Targeting HER2 in breast cancer: Overview of long-term experience. Int J Womens Health 2010;1:155-71.

15. Ménard S, Fortis S, Castiglioni F, Agresti R, Balsari A. HER2 as a prognostic factor in breast cancer. Oncology 2001;61 Suppl 2:67-72.

16. Wu J, Lee C, Yokom D, Jiang H, Cheang MC, Yorida E, et al. Disruption of the $Y$-box binding protein-1 results in suppression of the epidermal growth factor receptor and HER-2. Cancer Res 2006;66:4872-9.

17. Elston CW, Ellis IO. Pathological prognostic factors in breast cancer. I. The value of histological grade in breast cancer: Experience from a large study with long-term follow-up. Histopathology 1991;19:403-10.

18. Singletary SE, Connolly JL. Breast cancer staging: Working with the sixth edition of the AJCC cancer staging manual. CA Cancer J Clin 2006;56:37-47.

19. Chen N, Zhou Q. Constructing tissue microarrays without prefabricating recipient blocks: A novel approach. Am J Clin Pathol 2005;124:103-7.

20. Kononen J, Bubendorf L, Kallioniemi A, Bärlund M, Schraml P, Leighton $\mathrm{S}$, et al. Tissue microarrays for high-throughput molecular profiling of tumor specimens. Nat Med 1998;4:844-7.
21. Wolff AC, Hammond ME, Hicks DG, Dowsett M, McShane LM, Allison $\mathrm{KH}$, et al. Recommendations for human epidermal growth factor receptor 2 testing in breast cancer: American Society of Clinical Oncology/College of American Pathologists Clinical Practice Guideline update. Arch Pathol Lab Med 2014;138:241-56.

22. Zhao S, Wang Y, Guo T, Yu W, Li J, Tang Z, et al. YBX1 regulates tumor growth via CDC25a pathway in human lung adenocarcinoma. Oncotarget 2016;7:82139-57.

23. Moasser MM. The oncogene HER2: Its signaling and transforming functions and its role in human cancer pathogenesis. Oncogene 2007;26:6469-87.

24. Mitri Z, Constantine T, O'Regan R. The HER2 receptor in breast cancer: Pathophysiology, clinical use, and new advances in therapy. Chemother Res Pract 2012;2012:743193.

25. Xie W, Yang J, Cao Y, Peng C, Ning H, Zhang F, et al. Expression of Y-box-binding protein 1 in Chinese patients with breast cancer. Tumour Biol 2012;33:63-71.

26. Davies AH, Barrett I, Pambid MR, Hu K, Stratford AL, Freeman S, et al. YB-1 evokes susceptibility to cancer through cytokinesis failure, mitotic dysfunction and HER2 amplification. Oncogene 2011;30:3649-60.

27. Fujii T, Kawahara A, Basaki Y, Hattori S, Nakashima K, Nakano K, et al. Expression of HER2 and estrogen receptor alpha depends upon nuclear localization of Y-box binding protein-1 in human breast cancers. Cancer Res 2008;68:1504-12.

28. Mylona E, Melissaris S, Giannopoulou I, Theohari I, Papadimitriou C, Keramopoulos A, et al. Y-box-binding protein 1 (YB1) in breast carcinomas: Relation to aggressive tumor phenotype and identification of patients at high risk for relapse. Eur J Surg Oncol 2014;40:289-96. 